\title{
MENINGKATKAN HASIL BELAJAR IPS MENGGUNAKAN MEDIA GAMBAR BAGI SISWA KELAS IV SDN 002 BELAKANG PADANG
}

\author{
SARMAWATI \\ SDN 002 Belakang Padang Kota Batam \\ Sarmawati24.sw@gmail.com
}

\begin{abstract}
ABSTRAK
Penelitian ini bertujuan untuk meningkatkan hasil belajar IPS dengan menggunakan media gambar pada siswa kelas IV SDN 002 Belakang Padang Kota Batam. Penelitian ini adalah Penelitian Tindakan Kelas (Classroom Action Research) model Kemmis dan Mc. Taggart. Penelitian dilaksanakan pada semester II tahun ajaran 2016/2017 dalam dua siklus setiap siklus ada dua pertemuan. Subjek penelitian ini siswa kelas IV SDN 002 Belakang Padang Kota Batam yang berjumlah 25 siswa. Teknik pengumpulan data yang digunakan adalah tes, observasi dan dokumentasi. Sementara instrument pengumpulan data menggunakan soal tes, lembar observasi dan dokumen. Teknik analisis data dilakukan secara deskriptif kuantitatif. Hasil penelitian menunjukkan bahwa ada peningkatan hasil belajar IPS kelas IV SDN 002 Belakang Padang Kota Batam.. Hasil belajar saat pratindakan, rata-rata kelas adalah 65,76 untuk ketuntasan ada 12 siswa atau $48 \%$ dan belum tuntas ada 13 siswa atau 52\%. Hasil ini belum memenuhi KKM yaitu 70,00. Pada siklus I diperoleh peningkatan hasil rata-rata kelas71,92, ketuntasan ada 15 siswa atau $60 \%$ dan belum tuntas ada 10 siswa atau $40 \%$ berarti ada kenaikan nilai rata-rata pra tindakan ke siklus I sebesar 6,16, Sedangkan siklus II hasilnya mengalami kenaikan lagi yaitu rata-rata kelas meningkat menjadi 76,90 dan ketuntasan ada 22 siswa atau $88 \%$ dan belum tuntas ada 3 siswa atau $12 \%$, dengan demikian ada kenaikan rata-rata dari siklus I ke siklus II sebesar 4,98. Selain itu keaktifan siswa dalam mengikuti pelajaran juga meningkat. Hal ini ditandai dengan meningkatnya keaktifan siswa dalam bertanya, menjawab pertanyaan dan mengemukkan pendapat.
\end{abstract}

Kata kunci : Hasil Belajar IPS, Media Gambar.

\section{PENDAHULUAN}

Pendidikan sekolah dasar pada dasarnya merupakan lembaga pendidikan yang menyelenggarakan program pendidikan enam tahun bagi anak-anak usia 6-12 tahun. Pendidikan sekolah dasar dimaksud untuk memberikan bekal kemampuan dasar kepada anak didik berupa pengetahuan, keterampilan, dan sikap yang bermanfaat bagi dirinya sesuai dengan tingkat perkembangan. Jenjang pendidikan dasar merupakan peranan yang sangat penting dalam mengembangkan aspek fisik, intelektual, religius, moral, sosial, emosi, pengetahuan, dan pengalaman peserta didik. Melalui pendidikan dasar, diharapkan dapat menghasilkan manusia Indonesia yang berkualitas. Di masa yang akan datang, para siswa akan menghadapi tantangan yang cukup berat karena kehidupan masyarakat global yang selalu mengalami perubahan. 
Oleh karena itu, mata pelajaran IPS dirancang untuk mengembangkan pengetahuan, pemahaman, dan kemampuan analisis terhadap kondisi sosial masyarakat dalam memasuki kehidupan masyarakat yang dinamis (Suharjo, 2006: 1). Profesionalisme seorang guru sangatlah dibutuhkan guna terciptanya proses pembelajaran kreatif, efektif, dan efisien dalam pengembangan kemampuan siswa yang memiliki karakteristik yang beragam. Guru sebagai fasilitator dalam pendidikan harus mampu menumbuhkan minat belajar siswa. Dalam kegiatan pembelajaran, guru adalah orang yang akan mengembangkan pembelajaran demokratis bagi siswa untuk mengkaji apa yang menarik dan mengekspresikan ide-ide kreatif.

Di SDN 002 Belakang Padang Kota Batam., kegiatan pembelajaran terutama pelajaran IPS, masih dilakukan dengan metode yang belum bervariasi dan guru masih jarang menggunakan media pembelajaran sehingga kegiatan pembelajaran kurang efektif. Misalnya pada materi kenampakam alam, kebudayaan daerah dan kondisi sosial negara tetangga memerlukan media pembelajaran. Pendidikan di setiap jenjang perlu ditingkatkan, agar diperoleh kualitas sumber daya manusia Indonesia yang dapat menunjang pembangunan nasional. Guru merupakan institusi pendidikan yang bertanggung jawab dalam upaya peningkatan mutu pendidikan. Peningkatan mutu pendidikan dapat ditempuh dengan pembaharuan proses, metode, dan media sebagai sarana penyampaian pembelajaran.

Bagaimana pembelajaran yang disampaikan guru dapat dipahami oleh siswa secara benar. Dengan demikian, proses pembelajaran ditentukan sampai sejauh mana guru dapat menggunakan metode dan media pembelajaran dengan baik. Menurut (Santoso S. Hamidjojo dalam Ahmad Rohani, 1997: 2) media adalah semua bentuk perantara yang dipakai orang menyebarkan ide, sehingga ide atau gagasan itu sampai pada penerima. Guru menggunakan media pembelajaran yang interaktif, kreatif, dan menarik dapat memicu keingintahuan siswa. Hal itu tidak lepas dari kemampuan guru untuk membuat, mencari, mengelola, dan menggunakan media dengan tepat sehingga akan bermanfaat saat digunakan.

Berdasarkan hasil observasi di kelas dan wawancara dengan guru kelas IV SDN 002 Belakang Padang dalam pembelajaran IPS menunjukkan bahwa proses pembelajaran masih bersifat teacher center karena metode yang digunakan belum bervariasi, sehingga siswa kurang mendapatkan kesempatan untuk aktif berfikir, mengeluarkan pendapat, berinteraksi dengan teman sekelasnya, dan siswa merasa bosan.

Guru kelas IV SDN 002 Belakang Padang Kota Batam. dalam proses pembelajaran sudah menggunakan buku paket sebagai sumber belajar di kelas, tetapi belum semua siswa mendapatkan dikarenakan jumlah yang tidak mencukupi. Guru dalam menyampaian materi pelajaran IPS hanya menjelaskan pokok-pokok materi setelah itu siswa disuruh mengerjakan lembar kerja, sehingga pembelajaran kurang menarik dan untuk konsep-konsep yang bersifat abstrak masih belum divisualisasikan.

Observer mengamati sebagian besar siswa kelas SDN 002 Belakang Padang Kota Batam. kurang menyenangi pelajaran IPS karena menurut siswa banyak materi pelajaran yang membosankan dan penuh dengan hafalan-hafalan khususnya sejarah. Guru dalam proses pembelajaran belum menggunakan media yang dapat membantu dalam menjelaskan pemahaman siswa mengenai materi pelajaran. Sementara alternatif 
yang bisa ditempuh oleh seorang guru dalam rangka meningkatkan hasil belajar adalah dengan menggunakan media pembelajaran. Penggunaan media secara tepat dan bervariasi mempunyai nilai praktis antara lain: mengatasi keterbatasan pengalaman belajar siswa, mengkonkritkan pesan yang abstrak, menanamkan konsep dasar yang benar, menimbulkan keseragaman dan akhirnya gilirannya dapat meningkatkan mutu pembelajaran (Oemar Hamalik, 1986: 15).

Berdasarkan masalah di atas, guru hendaknya menggunakan media dan metode yang inovatif untuk meningkatkan proses pembelajaran di kelas. Penggunaan media pembelajaran bukan sekedar upaya untuk membantu guru dalam mengajar, tetapi lebih dari itu sebagai usaha memudahkan siswa dalam mempelajari materi pelajaran. Akhirnya media pembelajaran memang pantas digunakan oleh guru, bukan hanya sekedar alat bantu mengajar bagi guru, namun diharapkan akan timbul kesadaran baru bahwa media pembelajaran telah menjadi bagian integral dalam sistem pendidikan, sehingga dapat dimanfaatkan semaksimal mungkin untuk membantu kelancaran bidang tugas yang diemban untuk kemajuan dan meningkatkan kualitas peserta didik. Anak sebagai subyek pembelajaran memiliki kekuatan psikopisik, jika memperoleh sentuhan tepat akan mendorong anak berkembang dalam kapasitas mengagumkan. Oleh karena itu, pendidik harus membangun kemampuan pada dirinya agar dapat merubah gaya-gaya mengajar bersifat tradisional menjadi gaya mengajar modern, sehingga guru mengajar dengan luwes dan gembira (Oemar Hamalik, 1986 : 13-14).

Media gambar dimaksud dalam penelitian adalah Flat opaque picture, yaitu gambar datar yang tidak tembus pandang berupa gambar, foto, gambar fotografi, ilustrasi dan lukisan cetak. Media gambar yang dominan dipakai adalah media gambar foto yang berupa, foto alat komunikasi dan foto alat transportasi. Media gambar ini mudah pengadaannya dan biasanya relatif murah. Jadi media gambar adalah media dipergunakan untuk memvisualisasikan atau menyalurkan pesan dari sumber ke penerima (siswa). Pesan yang akan disampaikan dituangkan ke dalam komunikasi visual, di samping itu media gambar berfungsi pula untuk menarik perhatian, memperjelas sajian ide, mengilustrasikan atau menghiasi fakta yang mungkin akan cepat dilupakan atau diabaikan bila tidak digrafiskan. Penggunaan media gambar dalam proses kegiatan pembelajaran akan memberikan hasil belajar IPS yang optimal jika digunakan secara tepat. Berdasarkan latar belakang di atas peneliti tertarik untuk melakukan penelitian tindakan kelas dengan judul "meningkatkan hasil belajar IPS menggunakan media gambar bagi siswa kelas IV SDN 002 Belakang Padang

\section{METODE PENELITIAN}

Penelitian ini termasuk penelitian tindakan kelas (classroom action research) kolaborasi. Menurut (Wina Sanjaya, 2009: 13) PTK merupakan salah satu upaya yang dapat dilakukan guru untuk meningkatkan kualitas peran dan tanggung jawab guru khususnya dalam pengelolaan pembelajaran. Menurut Kemmis dan Taggart (Suwarsih Madya, 1994: 2), bahwa: "Penelitian tindakan kelas adalah suatu bentuk penelitian refleksif diri kolektif yang dilakukan oleh peserta-pesertanya dalam situasi sosial untuk meningkatkan penalaran dan keadilan praktik pendidikan dan praktik sosail mereka, serta pemahaman terhadap praktik-paraktik itu terhadap situasi tempat dilakukan praktik-praktik tersebut". 
Penelitian Tindakan Kelas adalah suatu bentuk kajian yang bersifat reflektif, yang dilakukan oleh peleku tindakan untuk meningkatkan kemantapan rasional dari tindakan dalam melaksanakan tugas dan memperdalam pemahaman terhadap kondisi dalam pratik pembelajaran (Hopkins dalam Muslich, 2011: 8). Penelitian Tindakan kelas merupakan suatu pencermatan terhadap kegiatan yang sengaja dimunculkan, dan terjadi dalam sebuah kelas (Zainal Aqib, 2006:13). Dari beberapa definisi penelitian tindakan kelas di atas bahwa penelitian tindakan kelas adalah suatu penelitian yang dilakukan berdasarkan suatu masalah di kelas dalam bentuk tindakan tertentu yang bertujuan untuk memperbaiki dan meningkatkan pembelajaran.

Tujuan utama dari Penelitian Tindakan Kelas yaitu untuk memperbaiki dan meningkatkan kualitas pembelajaran. Perbaikan tersebut dilaksanakan secara bertahap dan terus menerus selama penelitian dilakukan. Dalam penelitian ini peneliti menggunakan Model Kemmis dan Mc Taggart (1988) yang dikenal dengan model spiral (Suharsimi Arikunturo, 2006). Rancangan penelitian yang akan ditempuh dalam penelitian tindakan dengan 2 Siklus yang terdiri dari berapa tahapan a. Tahap Perencanaan b. Tahap Pelaksanaan Tindakan c. Pengamatan /observasi dan Refleksi Dari jabaran siklus di atas dapat disimpulkan bahwa pengertian siklus adalah suatu putaran kegiatan yang terdiri dari: (1) perencanaan (planning), (2) pelaksanaan/tindakan (action), (3) pengamatan/Observasi (obseving), dan (4) refleksi (reflecting). Siklus kedua akan dilaksanakan dengan tahap yang sama apabila pada siklus pertama belum mencapai indikator keberhasilan/tujuan sebegitu seterusnya.

Penelitian tindakan kelas ini telah dilaksanakan di kelas IV SDN 002 Belakang Padang . Setting penelitian ini dalam suasana pembelajaran di dalam kelas. Seluruh siswa kelas IV rata-rata umur siswa 9-12 tahun Subjek penelitian ini adalah siswa kelas IV semester genap yang berjumlah 25 siswa terdiri dari 11 siswa perempuan dan 14 siswa laki-laki. Alasan peneliti memilih kelas IV sebagai sujek penelitian karena berdasarkan observasi peneliti menemukan permasalahan bahwa pada siswa kelas IV hasil belajar IPS masih rendah. Hal ini dikarenakan pembelajaran belum menggunakan metode dan media pembelajaran yang tepat. dan Objek penelitian ini adalalah hasil belajar IPS menggunakan media gambar bagi siswa kelas IV SDN 002 Belakang Padan

Metode pengumpulan data merupakan langkah yang paling utama dalam penelitian, karena bertujuan utama dari penelitian adalah mendapatkan data, maka peneliti tidak akan mendapatkan data yang memenuhi data yang ditetapkan (Sugiyono, 2008 : 308). Metode pengumpulan data dalam Penelitian Tindakan Kelas meliputi 1 . Observasi 2. Tes 3. Dokumentasi ,Sedangkan Teknik Analisis Data (Suharsimi Arikunto, 2006: 131-132) mengatakan bahwa dalam penelitian tindakan kelas ada dua jenis data yang dapat dikumpulkan peneliti yaitu data kulitatif dan kuantitaitf. Dalam penelitian ini, peneliti menganalisis deskripsi kualitatif melalui lembar observasi dan deskripsi kuantitatif melalui tes hasil belajar. Pedoman kriteria keberhasilan yang digunakan adalah pedoman kreteria keberhasilan pembelajaran IPS pada kelas IV SDN 006 Sekupang. Penelitian ini bertujuan untuk meningkatkan hasil belajar siswa pada mata pelajaran IPS. Indikator keberhasilannya yaitu jika minimal $75 \%$ siswa atau sebesar 19 dari 25 siswa yang mengikuti proses pembelajaran memperoleh nilai KKM $\geq 70$ 


\section{HASIL DAN PEMBAHASAN}

\section{Deskripsi Data Awal Siswa Pra Siklus}

Data awal yang peneliti anggap sebagai pedoman awal melakukan penelitian yaitu menggunakan hasil tes semester I. Data tersebut nantinya digunakan sebagai patokan awal sebelum dilakukan tindakan. Penelitian ini dimulai dengan observasi dan wawancara dengan guru kelas IV. Berdasarkan wawancara dan observasi, permasalahan yang terjadi di dalam kelas tersebut diantaranya adalah guru belum menggunakan media pembelajaran secara optimal dan belum menggunakan metode yang bervariasi. Hal tersebut menyebabkan siswa kurang antusias dalam proses pembelajaran dan cenderung siswa pasif dalam proses pembelajaran.

Hal di atas menyebabkan hasil belajar IPS siswa kurang optimal. Berdasarkan hasil pengamatan, maka perlu diadakan suatu tindakan untuk mengatasi permasalahn di atas. Adapun data awal sebelum tindakan adalah , dari 25 siswa, sebanyak 12 siswa atau $48 \%$ sudah tuntas atau mencapai KKM. Sebanyak 13 siswa atau 52\% belum tuntuas atau belum mencapai KKM. Rata-rata kelas sebesar 65,76. Untuk memperjelas pemaparan tabel tersebut, dapat dilihat dalam diagram sebagai berikut ini :

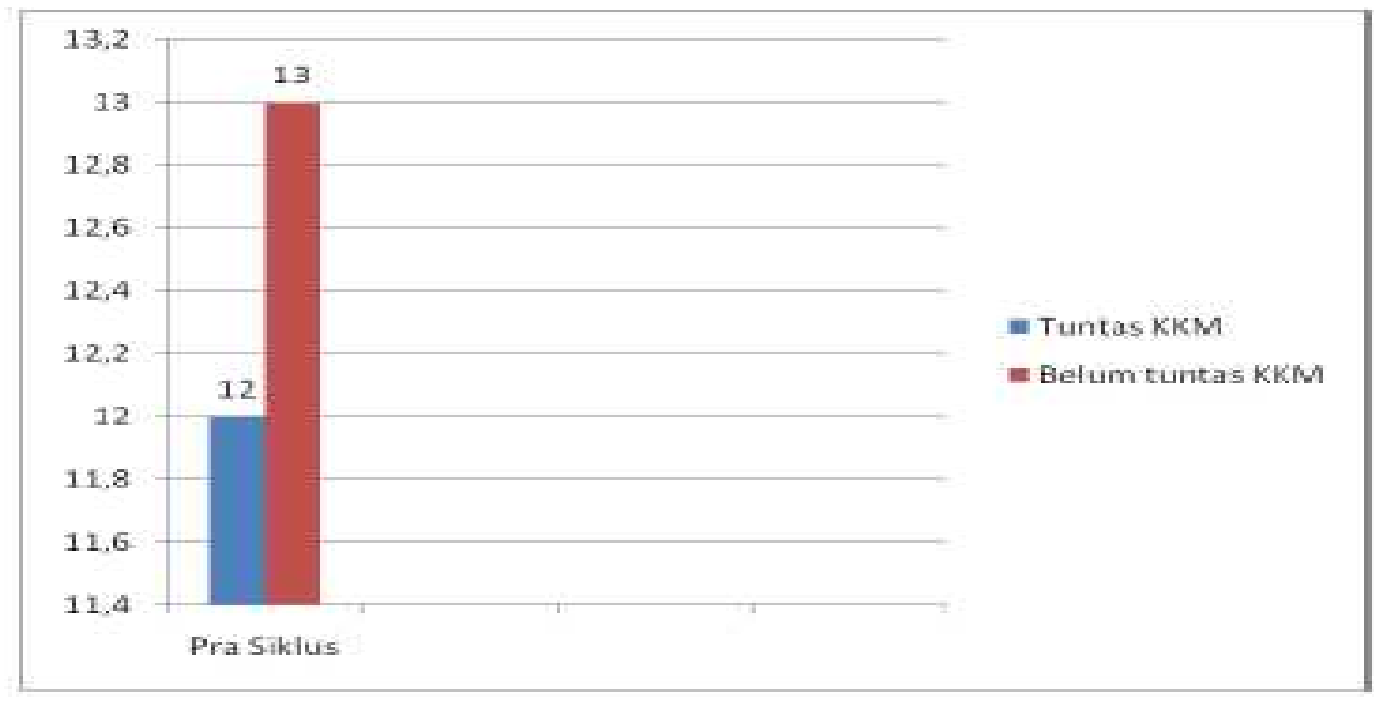

\section{Gambar 1. Diagram pencapaian KKM Pra Siklus}

\section{Deskripsi Hasil Penelitian}

Pada siklus I Dari 25 siswa sebanyak 15 siswa atau 60\% sudah tuntas atau mencapai KKM. Sebanyak 10 siswa atau $40 \%$ belum tuntas atau belum mencapai KKM. Ratarata kelas sebesar 71,92 untuk memperjelas pemaparan tabel tersebut, dapat dilihat dalam diagram berikut ini : 


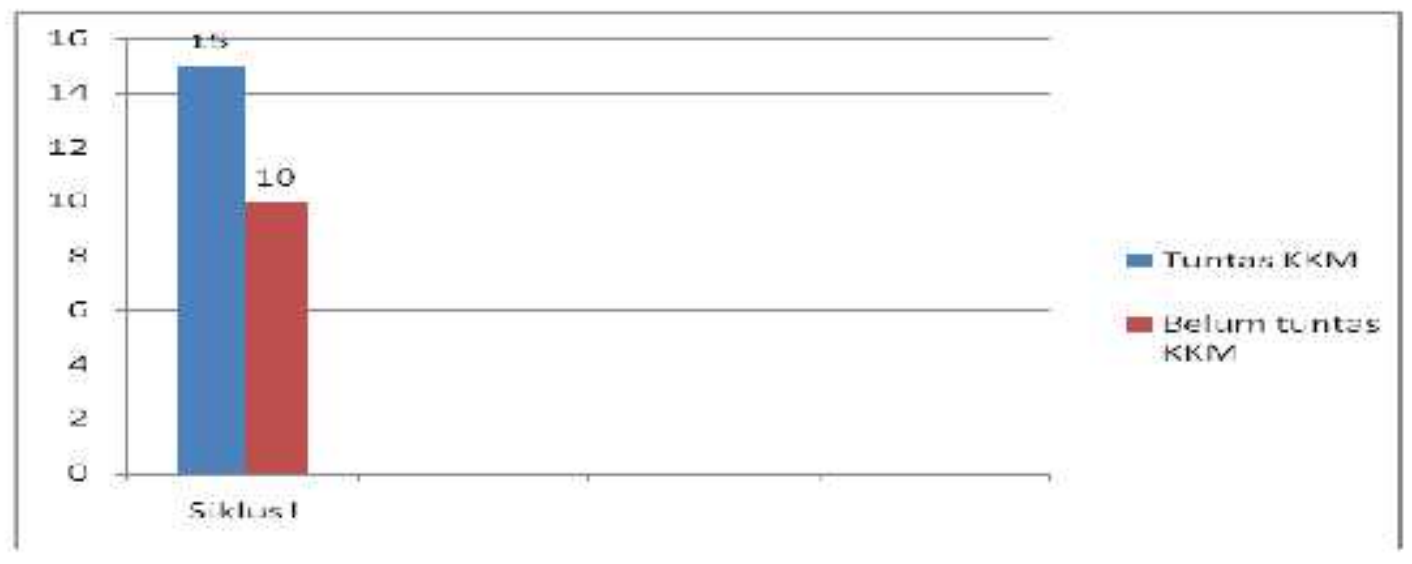

\section{Gambar 2. Diagram Pencapaian KKM Siklus II}

Untuk mengetahui peningkatan hasil belajar dari pra siklus ke siklus I, antara nilai siswa pada pra siklus yang belum dikenai tindakan dengan siklus I yang telah dikenai tindakan mengalami kenaikan. Nilai rata-rata kelas pada pra siklus 65,76 sedangkan pada siklus I mencapai 71,92. Persentase ketuntasan siswa yang sudah mencapai KKM dari seluruh siswa juga mengalami kenaikan. Pada pra siklus 48\%, sedangkan pada siklus I mencapai $60 \%$. Pada siklus I persentase ketuntasan siswa belum mencapai KKM masih kurang dari 75\%, sehingga penelitian dilanjutkan ke siklus II.

Hasil pengamatan yang dilakukan peneliti menunjukkan bahwa pembelajaran IPS pada siklus I berjalan dengan baik meskipun hasil belajar yang diperoleh belum semua siswa mencapai nilai KKM, sehingga perlu dilanjutkan pada siklus berikutnya. Observasi ini dilakukan terhadap aktivitas guru dan siswa dalam proses pembelajaran pada materi teknologi komunikasi masa lalu dan masa kini.

Pada Siklus II dari 25 siswa sebanyak 22 siswa atau $88 \%$ sudah tuntas atau mencapai KKM. Sebanyak 3 siswa atau $12 \%$ belum tuntas atau belum mencapai KKM. Rata-rata kelas 79,6. Untuk memperjelas pemaparan tabel tersebut, dapat dilihat dalam diagram berikut ini

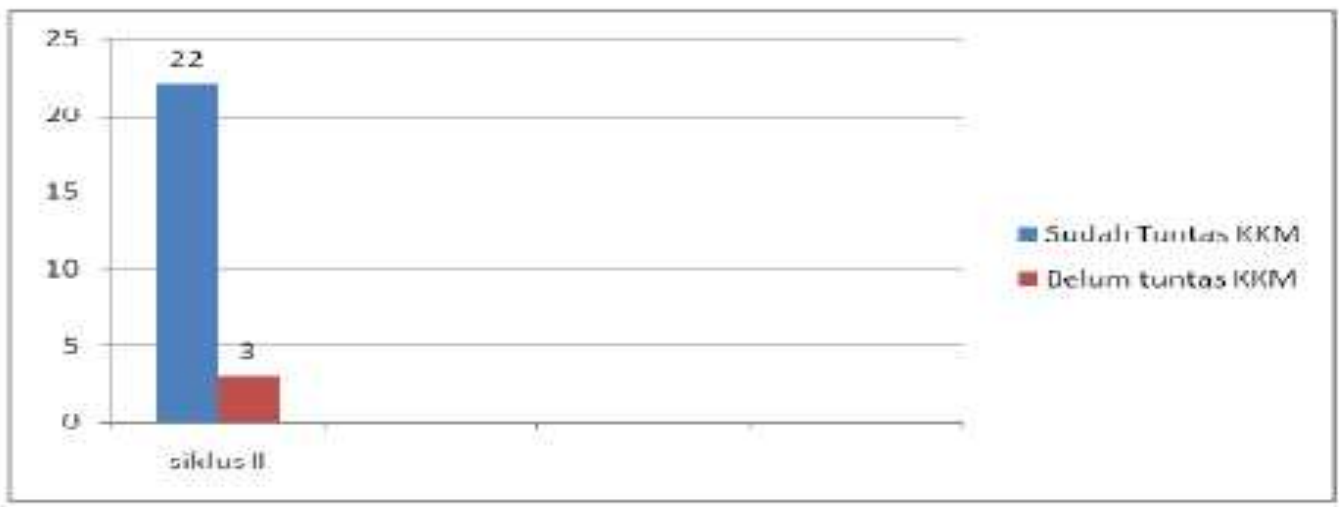

Gambar 3. Diagram Pencapaian KKM Siklus II 
Untuk mengetahui peningkatan hasil belajar dari siklus I ke siklus II, dapat dilihat pada tabel di bawah ini:

Tabel 1. Daftar Nilai Hasil Belajar Siklus I dengan Siklus II

\begin{tabular}{|c|c|c|c|c|c|c|c|c|c|}
\hline \multicolumn{2}{|c|}{$\begin{array}{c}\text { Rata-rata } \\
\text { kelas }\end{array}$} & \multicolumn{4}{|c|}{ Ketuntasan } & \multicolumn{4}{|c|}{ Persentase } \\
\hline I & II & & & & & & Is I & Sik & II \\
\hline $\mathrm{T}$ & BT & $\mathrm{T}$ & BT & $\mathrm{T}$ & BT & $\mathrm{T}$ & BT & $\mathrm{T}$ & B \\
\hline 71,92 & 79,6 & 15 & 10 & 22 & 3 & $60 \%$ & $40 \%$ & $88 \%$ & $12 \%$ \\
\hline
\end{tabular}

Berdasarkan tabel di atas dapat dilihat bahwa pada siklus II mengalami peningkatan dari siklus I hal ini dapat dibuktikan pada rata-rata kelas meningkat 4,78\% dan pada siklus I siswa yang meningkat 15 sedangkan pada sikuls II ada 22 siswa.

Hasil pengamatan yang dilakukan pada siklus II ini menunjukkan bahwa siswa lebih aktif, antusias, dan serius dalam mengikuti kegiatan pembelajaran. Pelaksanaan siklus II terlihat lebih bagus dari pada siklus I, hal ini terbukti dengan semakin meningkatnya hasil evaluasi di akhir siklus II. 87

Peningkatan pada siklus II dengan media gambar ternyata memberikan hasil yang memuaskan sesuai dengan yang telah direncanakan. Untuk mengetahui lebih jelasnya peningkatan hasil belajar dapat dilihat dari tabel 2 berikut ini :

\begin{tabular}{|c|c|c|c|c|c|c|c|c|}
\hline \multicolumn{9}{|c|}{ Daftar NUai Hasil Belajar l'ra Siklus, Siklns I dan Slklus II } \\
\hline \multicolumn{6}{|c|}{ Keluntasan } & \multicolumn{3}{|c|}{ Rata-rala } \\
\hline \multicolumn{2}{|c|}{ l'ra Siklus } & \multicolumn{2}{|c|}{ siklus 1} & \multicolumn{2}{|c|}{ Siklus II } & \multirow{2}{*}{$\begin{array}{c}\text { l'ra } \\
\text { Siklus }\end{array}$} & \multirow{2}{*}{ Siklus 1} & \multirow{2}{*}{ Siklus 1} \\
\hline $\mathrm{T}$ & TBT & $\mathbf{T}$ & BT & $\mathrm{T}$ & BT & & & \\
\hline 12 & 13 & 15 & 10 & 22 & 3 & 65,76 & 71,92 & 76,9 \\
\hline
\end{tabular}

Sumber : T.anquiva halaman 115 


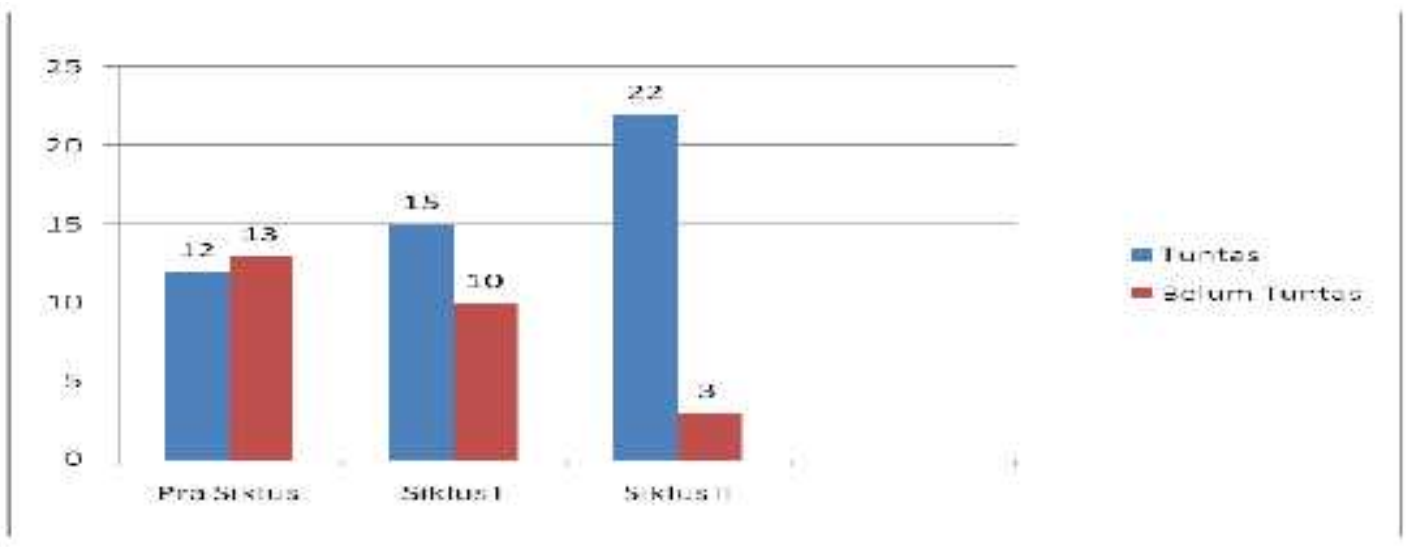

\section{Gambar 4. Diagram Peningkatan jumlah siswa yang telah mencapai KKM}

Berdasarkan data di atas dapat diketahui bahwa adanya peningkatan hasil belajar. Hal ini dapat dilihat pada rata-rata kelas. Dari pra siklus ke siklus I, yaitu sebasar 6,16 dari 65,76 menjadi 71,92. Dari siklus I ke siklus II mengalami peningkatan sebesar 4,98 dari 71,92 menjadi 76,9. Selain dari rata-rata kelasnya, peningkatan juga terjadi pada nilai ketuntasan siswa. Jumlah siswa yang mendapatkan nilai dari pra siklus ke siklus I mengalami peningkatan sebanyak 3 atau $12 \%$ dari seluruh siswa, sedangkan dari siklus I ke siklus II sebanyak 7 atau $28 \%$ dari seluruh siswa. Berdasarkan hal tersebut, kriteria keberhasilan pada pra siklus belum tercapai karena pencapaian KKM hanya $48 \%$ dari seluruh siswa. Kemudian pada siklus I meningkat menjadi $60 \%$ dan pada siklus II meningkat lagi menjadi $88 \%$. Berdasarkan data tersebut, maka penelitian ini telah tercapai karena lebih dari 75\% siswa mencapai KKM. Untuk memperjelas dapat dilihat pada diagram berikut ini:

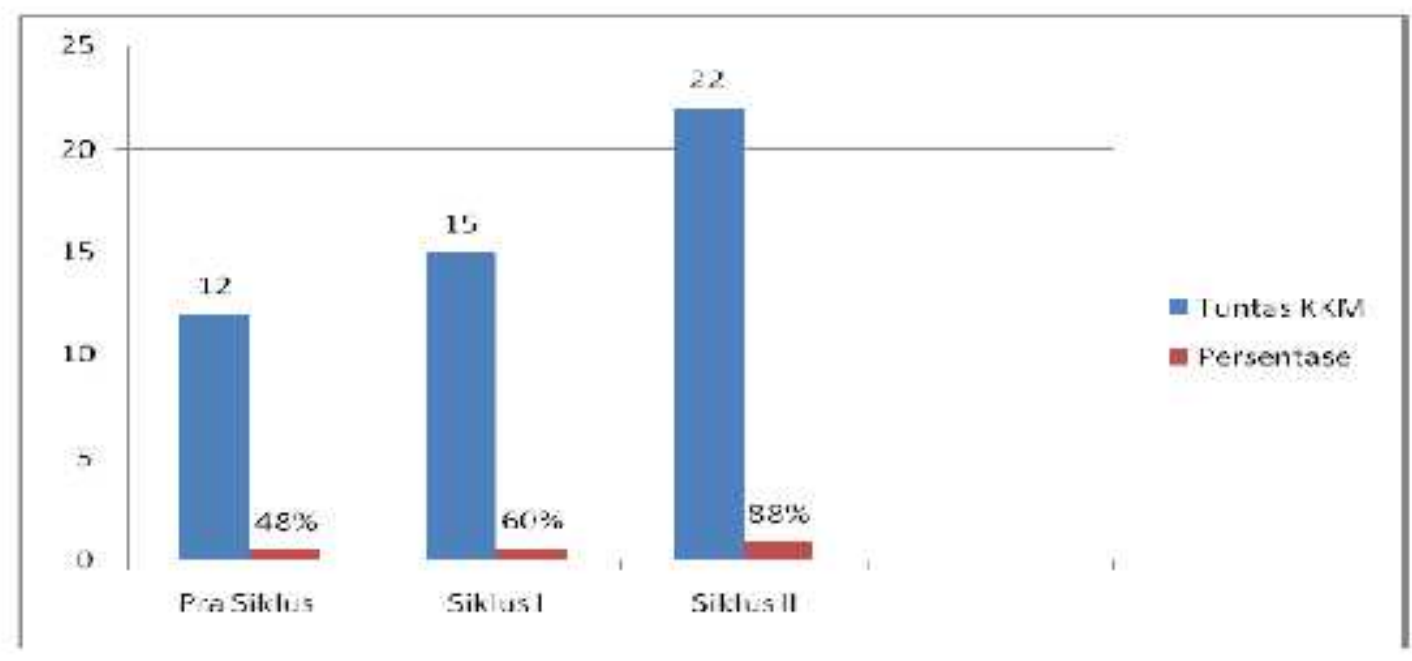

Gambar 5. Diagram Peningkatan jumlah siswa yang telah mencapai KKM 


\section{PEMBAHASAN}

Dalam pembahasan ini diuraikan hasil penelitian mengenai peningkatan hasil belajar IPS melalui media gambar. Berdasarkan penelitian, penggunaan media gambar ternyata dapat meningkatkan hasil belajar IPS pada siswa kelas IV SDN 002 Belakang Padang, Hal ini dikarenakan pembelajaran menggunakan media gambar dalam proses pembelajaran dapat menarik perhatian siswa sehingga membantu meningkatkan pemahaman siswa terhadap materi yang disampaikan oleh guru. Dalam penggunaan media gambar, guru dapat menerapkan berbagai metode dan model-model pembelajaran yang menarik dalam penyampiaan materi sehingga siswa tidak merasa jenuh dan merasa diceramahi. Guru bisa menggunakan model picture and picture, examples non examples, dan metode lain yang relevan dengan materi pelajaran. Hal ini sesuai dengan pendapat Hamalik (Arsyad, 2003: 15), bahwa media pembelajaran dapat menumbuhkan motivasi dan rangsangan belajar siswa karena pengajaran akan lebih menarik perhatian siswa, dan membantu meningkatkan pemahaman siswa.

Dengan menggunakan media gambar selama 2 siklus telah menunjukkan peningkatan hasil belajar IPS siswa kelas IV SDN 002 Belakang Padang Ini dibuktikan dengan adanya peningkatan hasil belajar, keaktifan dalam pembelajran pada siklus I ke siklus II. Hal ini sesuai dengan pendapat Sudjana dan Rivai (2002: 2), bahwa dengan media pembelajaran siswa lebih banyak melakukan aktivitas selama proses pembelajaran, tidak hanya mendengarkan tetapi mengamati, mendemostrasikan, melakkukan langsung dan memerankan. Hal di atas dapat dilihat dari peningkatan hasil belajar siswa yaiti nilai rata-rata kelas pada pra siklus sebesar 65,76 kemudian pada siklus I menjadai 71, 92 dan pada siklus II menjadai 79,6.

Jumlah siswa mampu mencapai KKM 70 pada pra siklus ada 12 siswa, pada siklus I ada 15 siswa, dan pada siklus II ada 22 siswa. Persentase ketuntasan pada pra siklus yaitu $48 \%$, siklus I yaitu $60 \%$ dan siklus II $88 \%$. Sehingga pada siklus II sudah lebih mencapai kriteria 75\% siswa mencapai KKM 70 dan bagi 3 siswa yang belum mencapai KKM akan diserahkan pada guru kelasnya untuk dilakukan remidial. Ketiga inisial nama siswa tersebut adalah $\mathrm{CH}, \mathrm{Y}$ dan S. Dari ketiga siswa tersebut dua diantaranya $\mathrm{CH}$ dan $\mathrm{S}$ belum mencapai $\mathrm{KKM}$ dikarenakan mereka adalah termasuk kedalam kelompok siswa yang berkemampuan rendah yang cenderung diam, dan kurang aktif dalam kegiatan tanya jawab. Sedangkan Y belum mencapai KKM dikarenakan pada siklus II berlangsung dia sedang dalam keadaan sakit sehingga selama pembelajaran dia terlihat kurang bersemangat, lesu, dan mengantuk. Solusi bagi ketiga siswa tersebut adalah diberikan remidial untuk memperbaiki nilai, dan khusus untuk Y remidial dilakukansetelah kondisinya sehat.

Berdasarkan hasil observasi pada pra siklus keaktifan siswa masih kurang, hal ini dikarenakan sebagian besar proses pembelajran masih dikuasai oleh guru dan guru belum menggunakan media pembelajran yang ada. Setelah dilakukan tindakan hasilnya mulai ada peningkatan. Pada siklus I keaktifan siswa mulai terlihat, meskipun yang aktif sebagian besar adalah siswa yang mempunyai keberanian, namun pada siklus II guru merencanakan untuk mengaktifkan siswa yang belum berani, dengan memberikan kesempatan untuk bertanya dan menjawab pertanyaan-pertanyaan yang diajukan guru sehingga siswa lebih meningkat dan merata. Untuk lebih menghidupkan suasana dan semangat siswa guru memberikan motivasi dengan memberikan hadiah pengahargaan 
kepada siswa terbaik. Pada siklus II guru meningkatkan kualitas pewarnaan dan grafis gambar sehingga siswa lebih tertarik dalam pembelajaran.

Berdasarkan hasil yang telah diperoleh dari siklus I sampai siklus II dapat disimpulkan bahwa dengan penggunaan media gambar dapat meningkatkan hasil belajar IPS siswa kelas IV SDN 002 Belakang Padang

\section{KESIMPULAN}

Media gambar yang digunakan dalam penelitian ini berupa gambar teknologi komunikasi dan teknologi transportasi. Dalam proses pembelajaran media gambar digunakan pada kegiatan awal, kegiatan inti dan kegiatan akhir Pada siklus I, penggunaan media gambar dalam pelajaran IPS dapat meningkatkan hasil belajar siswa dari nilai rata-rata kelas 65,76 menjadi 71,92 dan jika dilihat dari pencapaiaan KKM nilai ini sudah mencapai KKM. Kemudian pada siklus II, nilai rata-rata siswa meningkat lagi menjadi 76,90. Nilai tersebut sudah mencapai KKM dan telah mencapai target dimana lebih dari $75 \%$ siswa memperoleh nilai lebih dari 70,00. Hasil pengamatan sikap siswa, dari siklus I ke siklus II mengalami peningkatan. Ini dibuktikan dengan keaktifan siswa yang meningkat. Dari uraian diatas, dapat disimpulkan bahwa hasil belajar dan keaktifan siswa kelas IV SDN 002 Belakang padang meningkat dengan menggunaan media gambar pada mata pelajaran IPS. Disarankan kepada guru menerapkan penggunaan media gambar bukan hanya pada pembelajaran IPS tetapi pembelajaran lain seperti PKn dan peneliti menyampaikan saran media gambar dalam upaya meningkatkan hasil belajar IPS merupakan media yang cukup efektif untuk diterapkan di kelas, sehingga tercipta pembelajaran yang lebih menarik dan siswa terbantu dalam memahami materi IPS yang cenderung banyak hafalan.

\section{DAFTAR PUSTAKA}

Arief S.Sadiman, dkk. (2009). Media Pendidikan, Pengertian, Pengembangan, dan Pemanfaatan. Jakarta: Rajawali Pers.

Azhar Arsyad. (2002). Media Pembelajaran. Jakarta: PT Raja Grafindo Persada.

Basuki Wibawa, dkk. (1991). Media Pengajaran. Jakarta: Departemen Pendidikan dan Kebudayaan.

Daryanto. (2010). Media Pembelajaran. Yogyakarta: Gava Media.

Desmita.(2011).Psikologi Perkembangan Pesrta Didik.Bandung: PT Remaja Rosdakarya.

Dinas Pendidikan DIY. (2006). Model Kurikulum Tingkat Satuan Pendidikan Kelas Sekolah Dasar. Yogyakarta: Dinas Pendidikan DIY.

Fakih Samlawi Bunyamin.(1998). Konsep Dasar IPS. Jakarta: Depdikubud

Hamid Hasan \& Asmawi Zainul.(1991). Evaluasi Hasil Belajar. Jakarta: Departemen Pendidikan dan Kebudayaan.

Hidayati.(2004). Pendidikan Ilmu Pengetahuan Sosial di Sekolah Dasar. Yogyakarta: Universitas Negeri Yogyakarta.

Nursid Sumaatmadja, dkk. (2008). Konsep Dasar IPS. Jakarta: Universitas Terbuka. 
Usman Samatowa. (2004). Bagaimana Membelajarkan IPA di Sekolah Dasar. Jakarta: Depdikbud.

Nana Sujana.(2005). Penilaian Hasil Proses Hasil Mengajar. Bandung: PT Remaja Rosdakarya.

Nana Sudjana dan Ahmad Rivai. (2002). Media Pengajaran. Bandung: Sinar Baru Algesindo.

Nurul Zuriah dan Hari Sunaryo. (2008). Inovasi Model Pembelajaran Demokratis Berperspektif Gender. Malang: UMM Press. 